ECONOMICS as RELIGION 

Robert H. Nelson

\section{ECONOMICS as RELIGION}

from Samuelson to Chicago and Beyond

foreword by Max Stackhouse

THE PENNSYLVANIA STATE UNIVERSITY PRESS

University Park, Pennsylvania 
LIBRARY OF CONGRESS CATALOGING-IN-PUBLICATION DATA

Nelson, Robert H. (Robert Henry), 1944-

Economics as religion : from Samuelson to Chicago and beyond / Robert H. Nelson. p. $\mathrm{cm}$.

Includes bibliographical references and index.

ISBN 0-271-02095-4 (alk. pbk.)

1. Economics-Philosophy. 2. Economics-Moral and ethical aspects.

3. Religion-Economic aspects. I. Title.

HB72.N45 2001

$330.1-\mathrm{dc} 21$

00-052444

Copyright (C) 2001 The Pennsylvania State University

All rights reserved

Printed in the United States of America

Published by the Pennsylvania State University Press,

University Park, PA 16802-1003

It is the policy of The Pennsylvania State University Press to use acid-free paper for the first printing of all clothbound books. Publications on uncoated stock satisfy the minimum requirements of American National Standard for Information Sciences-Permanence of Paper for Printed Library Materials, ANSI Z39.48-1992. 
IN MEMORY OF PAUL HEYNE (1931-2000),

Whose Life Exemplified the Search for Truth 
